\title{
Dimensional comparisons in subject-specific academic self-concepts and achievements: A quasi-experimental approach ${ }^{\text {it }}$
}

\author{
Detlef H. Rost ${ }^{\mathrm{a}, *}$, Jörn R. Sparfeldt ${ }^{\mathrm{a}}$, Oliver Dickhäuser ${ }^{\mathrm{b}}$, \\ Susanne R. Schilling a \\ ${ }^{a}$ Philipps-Universität Marburg, Germany \\ ${ }^{\mathrm{b}}$ Friedrich-Alexander-Universität Erlangen-Nürnberg, Germany
}

\begin{abstract}
Even though marks in different subjects are substantially correlated, the corresponding self-concepts often display a very weak association. The "Internal-External Frame of Reference Model" (I/E-model; Marsh, H. W. (1986). Verbal and math self-concepts: an internal/external frame of reference model. American Educational Research Journal, 23, 129-149) explains this finding: social comparisons (resulting in positive correlations of the self-concepts) and dimensional comparisons (resulting in negative correlations of the self-concepts) are confounded. A rarely tested hypothesis derived from the I/E-model is that the dimensional comparison process only affects the self-concepts, if the students achieve differently in the corresponding subjects. In a sample of $N=1508$ students (grades 7 and 8), low correlations of the self-concepts for four subjects could be observed only in students displaying different school-marks in the corresponding subjects. In students who have the same marks in different subjects, the self-concepts showed a substantial positive correlation.
\end{abstract} (c) 2005 Elsevier Ltd. All rights reserved.

Keywords: Academic achievement; Academic self-concept; Dimensional comparison; Social comparison; Adolescents

\footnotetext{
Th This manuscript is an extended version of a paper published in Zeitschrift für Pädagogische Psychologie, 18 (2004), 43-52; additional statistical methods (e.g. CFA, multiple group comparisons) and references are added.

* Corresponding author. Philipps-Universität Marburg, Fachbereich Psychologie, Gutenbergstraße 18, D-35032 Marburg, Germany. Tel.: +496421 2821727; fax: +4964212823910.

E-mail address: rost@staff.uni-marburg.de (D.H. Rost).
} 
Student's beliefs about their abilities to learn and achieve affect their experiences and behaviour in many ways (see Marsh, 1990; Wigfield \& Karpathian, 1991). For example, academic self-concepts (hereafter called self-concepts) correspond with pupils' explanations of their accomplishments (Dickhäuser \& Stiensmeier-Pelster, 2002), they affect pupils' perseverance in carrying out tasks (Hallermann \& Meyer, 1978; see also Försterling \& Morgenstern, 2002), and the development of different expectations of success (Eccles, 1983). Academic self-concept affects both the choice of school subjects (e.g., Dickhäuser \& Stiensmeier-Pelster, 2003; Köller, Daniels, Schnabel \& Baumert, 2000; Meece, Eccles Parsons, Kaczala, Goff \& Futterman, 1982) and subsequent academic achievements (Guay, Marsh \& Boivin, 2003). Therefore, self-concept is an important topic in educational psychology (see Marsh \& Craven, 1997).

Students differentiate their self-concept by subjects (Marsh \& Shavelson, 1985; Rost \& Sparfeldt, 2002; Schilling, Sparfeldt, Rost, \& Nickels, 2005), and students' self-concepts are mainly based on the feedback they receive about their achievements. Previous research has revealed a surprising effect: although achievements (tests and/or marks) in different school subjects, e.g., verbal and mathematical, are correlated substantially, the corresponding self-concepts usually display a much lower correlation, often tending towards zero. According to Marsh (1986), the average correlation between verbal and mathematical achievements ranges between $r=0.42$ and $r=0.94$, but correlations of the accompanying self-concepts range only between $r=0.19$ and $r=-0.10$.

The Internal/External Frame of Reference Model (I/E-M, Marsh, 1986) offers an interesting explanation of this finding: according to this theory students simultaneously use two different frames of reference to evaluate their abilities and achievements in different domains (mathematical subjects vs. verbal subjects):

(a) External frame of reference (social comparison). Students compare their achievements with those of their peers (social comparison; see Festinger, 1954). It is a well-known fact that there is a positive relation between achievement scores from abilities and marks in different subjects. Therefore, a student is more likely to realise that his/her own achievements are better or worse in several different subjects (e.g. maths and German) if they use social (i.e., external) references.

(b) Internal frame of reference (dimensional, i.e. ipsative comparison). Students compare their achievement in one subject (e.g., maths) with their achievement in another subject (e.g., English). If their achievements in the subjects concerned differ, the resulting correlation of the self-concepts turns out to be negative.

Thus, "the external process predicts a positive correlation between verbal and math self-concepts, whereas the internal process predicts a negative correlation" (Marsh, 1986, pp. 133134). The joint operation of both frames of reference will therefore result in a small or even near-zero correlation of the self-concepts - depending on the relative strength of each process.

Social and dimensional comparisons in school are confounded, making it difficult to test each process separately. One simple methodological approach is to select groups of students for whom one of the two comparisons provides no information, or information that can be ignored: this keeps the effects of this process of comparison on the self-concept (relatively) constant. According to the I/E-M, a reasonable positive correlation between self-concepts would emerge if dimensional comparisons are switched off: in this case, self-concept formation will be primarily influenced by social comparisons. Incidentally, keeping one or more variables constant is a popular and effective control technique in experimental psychology, and this 


\section{دريافت فورى ـ ـ متن كامل مقاله}

\section{ISIArticles}

مرجع مقالات تخصصى ايران

ل امكان دانلود نسخه تمام متن مقالات انكليسى ل امكان دانلود نسخه ترجمه شده مقالات ل يذيرش سفارش ترجمه تخصصى $\checkmark$ ل امكان جستجو در آرشيو جامعى از صدها موضوع و هزاران مقاله ل امكان دانلود رايكان r صفحه اول هر مقاله

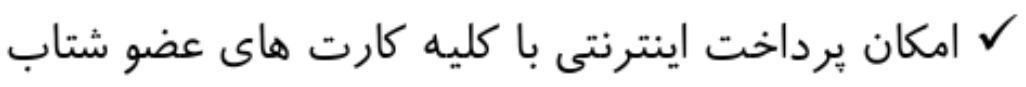
ل دانلود فورى مقاله پِ از برداخت آنلاين

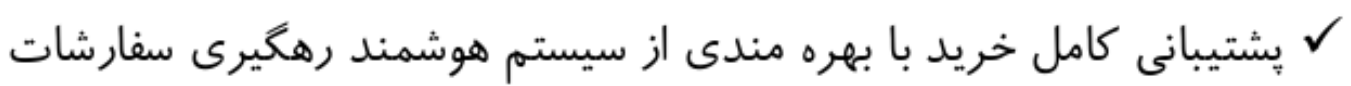

